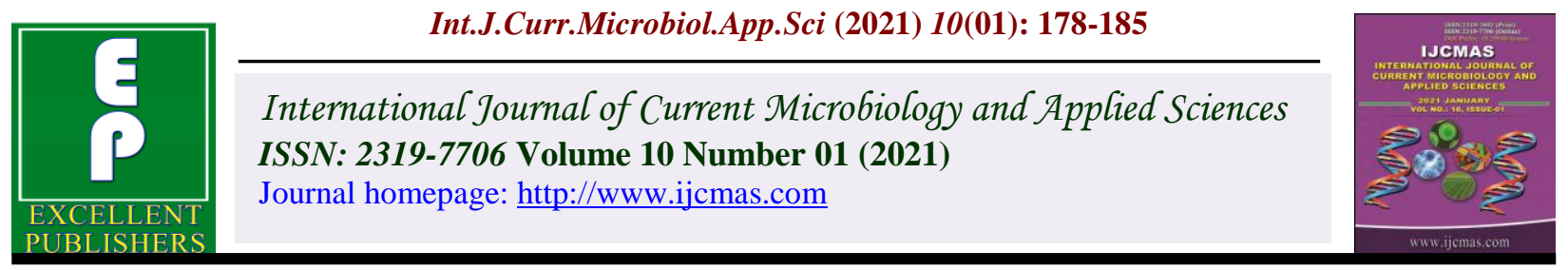

Original Research Article

https://doi.org/10.20546/ijcmas.2021.1001.021

\title{
Effect of Non-genetic Factors on Production Traits of for HF × GIR Halfbreds
}

\author{
Ghoshita Suryakant Hingonekar*, Dilip Kundalik Deokar, Swapnali Uttamrao Rokade \\ and Harshavardhan Shahaji Sonawane
}

Department of Animal Husbandry and Dairy Science, College of Agriculture, Dhule, Mahatma PhuleKrishiVidyapeeth, Rahuri, India

*Corresponding author

\section{A B S T R A C T}

\begin{tabular}{l} 
Ke y w o r d s \\
HF $\times$ Girhalfbreds, \\
TMY, LL, DP, \\
PMY, POC, SOC, \\
LO \\
\hline Article Info \\
$\begin{array}{l}\text { Accepted: } \\
\text { 04 December } 2020 \\
\text { Available Online: } \\
\text { 10 January } 2021\end{array}$ \\
\hline
\end{tabular}

\section{Introduction}

Increased pressure for intensified milk production and simultaneous rise in environmental temperature due to global warming has increased the thermal load on dairy animals. Elevated environmental temperature combined with high humidity causes discomfort and escalates the stress level in animals which is reflected in terms of reduced physiological and metabolic activities that results in reduced growth, drop in production and reproduction in farm animals. Heat stress is one of the most vital environmental stressor that has negative impact on milk yield, milk composition (fat $\%$, SNF\%, protein \% etc). Construction of Temperature Humidity Index (THI) by combining several climatological parameters like dry bulb, wet bulb temperature along with relative humidity to quantify the thermal stress is one of the best methods to assess heat stress on animals. Several research workers have reported that there exists a threshold THI value, above which the negative effects of heat stress is observed on animals. Mitigation strategies to combat heat stress includes selection of heat tolerant animals and their 
breeding, inclusion of heat tolerance as a trait while constructing selection index, providing balanced nutrition to the animals and implementation of good ventilation along with suitable cooling system in the farm (Behera et al., 2020).

\section{Materials and Methods}

The data of Phule Triveni cows maintained at Research Cum-Development Project on Cattle, M.P.K.V., Rahuri for a period from 2009 to 2019 (10 years) were collected for present investigation for following Traits:

a) Productive traits:1) Total lactation milk yield (kg),2) Lactation length (days),3) Dry period (days),4) Peak milk yield (kg).

To examine the Production traits, the research data was classified into 3 periods of calving viz. $\quad \mathrm{P}_{1} \quad$ (2009-2011), $\quad \mathrm{P}_{2}(2012-2014), \mathrm{P}_{3}$ (2015above);3 seasons of calving, viz. $\mathrm{S}_{1}$ (Rainy) June- September, $\mathrm{S}_{2}$ (Winter) October-January and $\mathrm{S}_{3}$ (Summer) FebruaryMay; 5 order of lactation viz. $\mathrm{L}_{1}$ first lactation, $\mathrm{L}_{2}$ second lactation, $\mathrm{L}_{3}$ third lactation, $\mathrm{L}_{4}$ fourth lactation, $\mathrm{L}_{5}$ fifth lactation

The effects of non-genetic factors like period of calving, season of calving and parity were estimated by using least-square analysis as suggested by Harvey (1990). The model was used with the assumption that different components being fitted into the model were as linear, independent and additive. The model used was as follows:

\section{Model I}

$Y_{i j k l}=\mu+A_{i}+B_{j}+C_{k}+e_{i j k l}$

where $Y_{i j k l}$, observation of $1^{\text {th }}$ animal, $k^{\text {th }}$ parity, $\mathrm{j}^{\text {th }}$ season of calving, $\mathrm{i}^{\text {th }}$ period of calving; $\mu$ overall mean, $A_{i}$ fixed effect of $i^{\text {th }}$ period of calving ( 1 to 3 ), $B_{j}$ fixed effect of $j^{\text {th }}$ season of calving (1 to 3 ), $\mathrm{C}_{\mathrm{k}}$ fixed effect of $\mathrm{k}^{\text {th }}$ parity (1 to 5$) ; \mathrm{e}_{\mathrm{ijk} l}$ random error $\sim$ NID $(0$, $\left.\sigma^{2} \mathrm{e}\right)$.

\section{Duncan's Multiple Range Test (DMRT)}

Duncan's Multiple Range Test as modified by Kramer (1957) was used to make pair wise comparison among the least square means with the use of inverse elements and root mean squares for error.

If the values:-

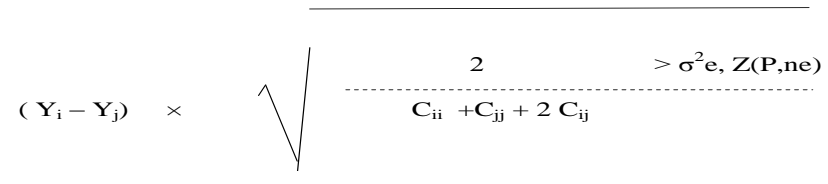

Where,

$Y_{i}-Y_{j}$ : Difference between two least squares means

$\mathrm{C}_{\mathrm{ii}}$ : Corresponding $\mathrm{i}^{\text {th }}$ diagonal elements of $\mathrm{C}$ matrix

$\mathrm{C}_{\mathrm{jj}}$ : Corresponding $\mathrm{j}^{\text {th }}$ diagonal elements of $\mathrm{C}$ matrix

$\mathrm{Z}$ ( $\mathrm{P}$, ne): Standardized range value in Duncan's table at the chosen level of probability for the error degrees of freedom

P: Number of means involved in the comparison

$\sigma^{2} \mathrm{e}$ : Root mean squares for error

\section{Results and Discussion}

Total milk yield (kg)

The overall least squares mean of total milk yield in $\mathrm{HF} \times$ Girhalfbreds was $2448.92 \pm$ $73.72 \mathrm{~kg}$. This was in accordance with Deokar 
(2003) in Gircrossberd cows. Whereas, higher values were reported by Ambhore et al., (2017) in Phule Triveni (2855 $\pm 43 \mathrm{~kg})$, Kamble et al., (2016) in Phule Triveni $(2835.05 \pm 57.47 \mathrm{~kg})$, Raut et al., (2017) in HF $\times$ Girhalfbreds $(2556.82 \mathrm{~kg})$, Jadhav et al., (2019) in HF $\times$ Girhalfbreds (2701.77 \pm 46.04 $\mathrm{kg}$ ), Gaikwad et al., (2018) in $\mathrm{HF} \times$ Girhalfbreds $(2703.10 \pm 97.91 \mathrm{~kg})$, However, Arya et al., (2013) in crossbred cows and Thombare et al., (2013) in HF $\times$ Deoni cows.

The influence of period of calving on total milk yield was significant $(\mathrm{P}<0.01)$. This was in accordance with Pandey M. et al., (2018) in Sahiwal cattle and Baranwal et al., (2018) in Vrindavani cows. In HF $\times$ Girhalfbreds, total milk yield $(\mathrm{kg})$ of cows calved during P1 $(2928.84 \pm 104.85 \mathrm{~kg})$ was significantly higher than those cows calved during period P2(2345.76 $\pm 108.88 \mathrm{~kg})$ and P3 (2072.16 \pm $163.45 \mathrm{~kg}$ ) which were at par to each other.

The variation due to season of calving in total milk yield was non-significant in $\mathrm{HF} \times$ Girhalfbreds. Similar results were obtained by Pandey et al., (2018) Sahiwal cattle, Ambhore et al., (2017) in Phule Triveni $(2855 \pm 43 \mathrm{~kg})$, Kamble et al,. (2016) in Phule Triveni, Raut et al., (2017) in HF $\times$ Girhalfbreds, Jadhav et al., (2019) in HF $\times$ Girhalfbreds, Gaikwad et al., (2018) in HF $\times$ Girhalfbreds. In presents study, the highest TMY was observed in cows calved during season winter (2532.30 \pm $114.38 \mathrm{~kg})$ followed by summer $(2435.48 \pm$ $117.47 \mathrm{~kg})$ and lowest in rainy $(2378.98 \pm$ $131.64 \mathrm{~kg})$.

The difference due to order of lactation in total milk yield $(\mathrm{kg})$ was non-significant in HF× Girhalfbreds. This was in accordance with Radhika et al., (2012) in crossbred cows. In $\mathrm{HF} \times$ Gir crossbreds, the highest TMY was observed in cows during L5 (2658.30 \pm 158.04) followed by L4 (2578.43 \pm 141.97$)$, L2 (2479.13 \pm 161.05), L3 (2458.66 \pm
147.16) and lowest in L1 (2070.05 \pm 167.87) lactation. In $\mathrm{HF} \times \mathrm{Gir}$ cows in the present study no specific trend of lactation lengths was noticed for total milk yield. The results revealed that the total milk yield linearly increased in cows calved during succeeding lactation order over preceding i.e. L1 to L5 in $\mathrm{HF} \times$ Gir cows.

\section{Lactation length}

The overall mean lactation length of $\mathrm{HF} \times \mathrm{Gir}$ cows recorded was $282.68 \pm 5.70$ days. Which was in close agreement with Shubha Laxmi et al., (2009) in HF $\times$ Sahiwal and Pol et al., (2013) in Phule Triveni cows. Whereas, higher lactation length were reported by Ambhore et al., (2017) in Phule Triveni cows (331.3 \pm 3 days), Jadhav et al., (2019) in $\mathrm{HF} \times$ Girhalfbreds (320.43 \pm 3.04days), Mote et al., (2019) in IFG (352.21 \pm 5.14 days) FG (327.22 \pm 4.15days), FIG (331.71 \pm 3.97days), IFJG (358.33 \pm 3.81days), R(343 \pm 7.52 days), Gaikwad et al., (2018) in HF $\times$ Girhalfbreds (332.80 \pm 8.72 days). However, lower lactation length was observed by Thombareet al., (2013) in HF $\times$ Deonicows.

The variation due to period of calving in lactation length was non-significant in $\mathrm{HF} \times$ Girhalfbreds. Thenon significant effect of period of calving on lactation length was also noticed by Jadhavet al., (2019) in HF $\times$ Girhalfbreds, Mote et al., (2019) in FG, FIG, Gaikwad et al., (2018) in HF×Girhalfbreds. However, significant effect of period of calving on lactation length was reported by Ambhore et al., (2017) in Phule Triveni cows, Mote et al., (2019) in IFGIFJG. In HF $\mathrm{x}$ Girhalfbreds, lactation length (days) was highest in cows calved during period P1(300.36 \pm 8.10$)$ followed by P2 (276.18 \pm 8.41) and lowest in P3 (271.51 \pm 12.63$)$.

The influence of season of calving on lactation length was non-significant in HF $\times$ 
Girhalfbreds. These results were in accordance with Ambhore et al., (2017) in Phule Triveni cows, Mote et al., (2019) in IFG, FG, FIG, R, Gaikwad et al., (2018) in HF $\times$ Girhalfbreds, Bhutkar et al., (2014) in Deoni cows. However, present results did not agreed with Patond (2013) in Gir triple cross cows, Kamble et al., (2016) in Phule Triveni cows, Mote et al., (2019) in IFJG. In HF $\times$ Girhalfbreds, the highest lactation length was observed in cows calved during winter S2 (294.05 \pm 8.84 days) season followed by rainy $\mathrm{S} 1(285.26 \pm 10.17$ days $)$ and lowest in summer $\mathrm{S} 3(268.73 \pm 9.08$ days $)$ season.

The effect of order of lactation on lactation length was non-significant in $\mathrm{HF} \times$ Girhalfbreds. These results were in accordance with Patond (2013) in Gir triple cross and Thombare et al., (2013) in HF $\times$ Deoni crossbred cows.

However, significant effect of order of lactation on lactation length was observed by Kamble (2003) in Gir crossbred cows and Jadhav (2011) in FG halfbreds. In HF $\times$ Girhalfbreds, the highest lactation length was observed in L1 (296.27 \pm 12.98 days) lactation followed by L5 (283.80 \pm 12.22 days), L3 (279.55 \pm 11.37 days), L4 (277.70 \pm 10.97 days) and lowest in L2 (276.08 \pm 12.45days) lactation. In $\mathrm{HF} \times$ Gir no specific trend of lactation length was noticed during different lactations.

\section{Dry period}

The overall mean dry period in $\mathrm{HF} \times$ Gir crossbreds was $151.51 \pm 8.44$ days. These results were in close agreement with Thakur and Singh (2001) in JH halfbreds, Pandey et al., (2009) in FJH, Usman et al., (2012) in HF cows, Hadge et al., (2012) in Jersey $\times$ Sahiwal cows and Hassan et al., (2013) in crossbred cows. However, lower values were noticed by Kamble (2003) in HG cows, Deokar et al., (2008) in Phule Triveni cows
$(93.57 \pm 4.94$ days $)$. The variation due to period of calving in dry period was significant $(\mathrm{P}<0.05)$ in $\mathrm{HF} \times$ Girhalfbreds. Similar results were noticed by Hadge et al., (2012) in Jersey $\times$ Sahiwal crossbred cows, Mruttu (2013) and Bhutkar et al., (2014) in Deoni cows, Kamble et al., (2016) in Phule Triveni cows, Ambhore et al., (2017) in Phule Triveni cows. In HF x Girhalfbreds, dry period (days) was largest in cows calved during period P3 (173.71 \pm 18.71) followed by P2 (158.23 \pm 12.46) and lowest in $\mathrm{P} 1(122.57 \pm 12.00)$. The results revealed that the dry period linearly increased in cows calved during succeeding period over preceding period i.e. $\mathrm{P} 1$ to $\mathrm{P} 3 \mathrm{HF}$ $\times$ Gir cows.

The variation due to season of calving in dry period was non-significant in $\mathrm{HF} \times$ Girhalfbreds. These results were in agreement with Ambhore et al., (2017) in Phule Triveni cows, Jadhav et al., (2019) in HF $\times$ Girhalfbreds and Bhutkar et al., (2014) in Deoni cows. However, the present results did not agree with Jadhav (2019) in HF $\times$ Girhalfbreds, Gaikwad et al., (2018) in HF $\times$ Girhalfbreds. In $\mathrm{HF} \times$ Girhalfbreds, the longest dry period was observed in cows calved during summer S3 (172.34 \pm 13.45 days) season followed by rainy $\mathrm{S} 1(146.70 \pm$ 15.07days) and shortest in those calved in winter S2(135.47 \pm 13.09 days) season.

The difference due to order of lactation in dry period was non-significant in $\mathrm{HF} \times$ Girhalfbreds. These results were similar to Zol et al., (2009) in Phule Triveni cows, Khade (2001) and Kamble (2003) in Gir crossbreds, Zol (2007) in Phule Triveni. In $\mathrm{HF} \times$ Girhalfbreds, the longest dry period (days) was observed in cows during L3 $(175.48 \pm 16.85)$ followed by L4 (167.17 $\pm 16.25)$, L1 (160.24 \pm 18.22), L5 (129.53 $\pm 18.09)$ and lowest in L2 (125.11 \pm 18.44) lactation. In $\mathrm{HF} \times \mathrm{Gir}$ cows in the present study no specific trend of dry period was noticed for different lactations (Table 1). 
Table.1 Least Square means of TMY, LL, DP and PMY in HF $\times$ Girhalfbreds

\begin{tabular}{|c|c|c|c|c|c|}
\hline Effect & $\mathbf{N}$ & TMY & $\mathbf{L L}$ & DP & PMY \\
\hline $\boldsymbol{\mu}$ & 169 & $2448.92 \pm 73.72$ & $282.68 \pm 5.70$ & $151.51 \pm 8.44$ & $15.21 \pm 0.34$ \\
\hline \multicolumn{6}{|l|}{$\begin{array}{l}\text { Period of } \\
\text { Calving }\end{array}$} \\
\hline $\mathbf{P}_{1}$ & 72 & $2928.84^{\mathrm{a}} \pm 104.85$ & $300.36 \pm 8.10$ & $122.57^{c} \pm 12.00$ & $16.86^{\mathrm{a}} \pm 0.48$ \\
\hline $\mathbf{P}_{2}$ & 67 & $2345.76^{\mathrm{ab}} \pm 108.88$ & $276.18 \pm 8.41$ & $158.23^{\mathrm{b}} \pm 12.46$ & $15.03^{\mathrm{ab}} \pm 0.50$ \\
\hline $\mathbf{P}_{3}$ & 30 & $2072.16^{\mathrm{b}} \pm 163.45$ & $271.51 \pm 12.63$ & $173.71^{\mathrm{a}} \pm 18.71$ & $13.74^{b} \pm 0.75$ \\
\hline \multicolumn{6}{|l|}{$\begin{array}{l}\text { Season of } \\
\text { Calving }\end{array}$} \\
\hline $\mathbf{S}_{1}$ & 47 & $2378.98 \pm 131.64$ & $285.26^{\mathrm{ab}} \pm 10.17$ & $146.70 \pm 15.07$ & $15.05 \pm 0.61$ \\
\hline $\mathbf{S}_{2}$ & 60 & $2532.30 \pm 114.38$ & $294.05^{\mathrm{a}} \pm 8.84$ & $135.47 \pm 13.09$ & $14.93 \pm 0.53$ \\
\hline $\mathbf{S}_{3}$ & 62 & $2435.48 \pm 117.47$ & $268.73^{c} \pm 9.08$ & $172.34 \pm 13.45$ & $15.66 \pm 0.54$ \\
\hline \multicolumn{6}{|c|}{ Lactation Order } \\
\hline $\mathbf{L}_{1}$ & 30 & $2070.05 \pm 167.87$ & $296.27 \pm 12.98$ & $160.24^{c} \pm 19.22$ & $12.21^{c} \pm 0.78$ \\
\hline $\mathbf{L}_{2}$ & 31 & $2479.13 \pm 161.05$ & $276.08 \pm 12.45$ & $125.11^{\mathrm{d}} \pm 18.44$ & $16.02^{\mathrm{b}} \pm 0.74$ \\
\hline $\mathbf{L}_{3}$ & 39 & $2458.66 \pm 147.17$ & $279.55 \pm 11.37$ & $175.48^{\mathrm{a}} \pm 16.85$ & $15.60^{\mathrm{bc}} \pm 0.68$ \\
\hline $\mathbf{L}_{4}$ & 38 & $2578.43 \pm 141.97$ & $277.70 \pm 10.97$ & $167.17^{b} \pm 16.25$ & $16.13^{\mathrm{a}} \pm 0.65$ \\
\hline $\mathbf{L}_{5}$ & 31 & $2658.33 \pm 158.04$ & $283.80 \pm 12.22$ & $129.53^{\mathrm{cd}} \pm 18.09$ & $16.10^{\mathrm{ab}} \pm 0.73$ \\
\hline
\end{tabular}




\section{Peak MilkYield}

The overall mean PMY was $15.21 \pm 0.34 \mathrm{~kg}$ which was in close agreement with Patond (2009) reported in Jersey cows, Shelke (2012) in Phule Triveni, whereas, higher values were observed by Patond (2013) in Gir triple cross cows. However, lower values were noticed by Kale et al., (2001) in FJG $(14.87 \pm 0.13 \mathrm{~kg})$ JFG $(14.57 \pm 0.25 \mathrm{~kg})$ and $\mathrm{BFG}(14.91 \pm 0.19$ $\mathrm{kg}$ ), Kamble (2003) in HG cows, Chakravarthy et al., (2002) in Ongole cows, Nanavati and Singh (2004) in Gir cattle.

The variation due to period of calving in PMY was significant $(\mathrm{P}<0.01)$ in $\mathrm{HF} \times$ Girhalfbreds. Which was also noticed by Balbir et al., (2011) in Tharparkar, Patond (2013) in Gir triple cross cows and Bhutkar et al., (2014) in Deoni cattle. However, nonsignificant effect of period of calving on PMY was noticed by Shelke (2012) in Phule Triveni cows. The PMY $(\mathrm{kg})$ of cows calved during period $\mathrm{P}_{1}(16.86 \pm 0.48)$ is significantly higher than $\mathrm{P}_{3}(13.74 \pm 0.75)$ and at par with those calved during $\mathrm{P}_{2}(15.03$ \pm 0.50 ). The differences in PMY among cows calved during $\mathrm{P}_{1}$ and $\mathrm{P}_{2}$ and between $\mathrm{P} 2$ and $\mathrm{P}_{3}$ were at par with each other.

The PMY (kg) of cows calved during period $\mathrm{P}_{1}(16.86 \pm 0.48)$ is significantly higher than $\mathrm{P}_{3}(13.74 \pm 0.75)$ and at par with those calved during $\mathrm{P}_{2}(15.03 \pm 0.50)$. The differences in PMY among cows calved during $\mathrm{P}_{1}$ and $\mathrm{P}_{2}$ and between $\mathrm{P} 2$ and $\mathrm{P}_{3}$ were at par with each other.

The variation due to season of calving in PMY was non-significant in HF $x$ Girhalfbreds. These results were in agreement with Shelke (2012) in Phule Triveni cows Bhutkar et al., (2014) in Deoni cattle and Radhika et al., (2012) incross bredcows. In HF $\times$ Girhalfbreds, the highest PMY was observed in cows calved during summer
$(15.66 \pm 0.54 \mathrm{Kg})$ season and lowest in winter $(14.93 \pm 0.53 \mathrm{Kg})$.

The difference in PMY due to order of lactation was significant $(\mathrm{P}<0.01)$ in $\mathrm{HF} \times$ Girhalf breds. Similar results were noticed by Kale et al., (2001) in FJG JFG and BFG, Kulkarni (2001) in Red Sindhi, Chakravarthy et al., (2002) in Ongole cattle, Nanavati and Singh (2004) Gir cattle and Patond (2013) in Gir triple cross cows. The PMY $(\mathrm{kg})$ of cows calved during order of lactation $\mathrm{L}_{4}(16.13 \pm$ $0.65)$ is significantly higher than $\mathrm{L}_{3}(15.60 \pm$ $0.68), \mathrm{L}_{2}(16.02 \pm 0.74)$ and $\mathrm{L}_{1}(12.21 \pm 0.78)$ and at par with those calved during $\mathrm{L}_{5}(16.10$ $\pm 0.73)$. The differences in PMY among cows calved during $\mathrm{L}_{4}$ and L5, between L5 and L3 and $L_{2}$ and were at par with each other. The significantly lower PMY was recorded in cows during L1 lactation.

In HF $\times$ Girhalfbreds, the highest PMY (kg) was observed during $\mathrm{L}_{4}(16.13 \pm 0.65)$ followed by, $\mathrm{L}_{5}(16.10 \pm 0.73), \mathrm{L}_{2}(16.02 \pm$ $0.74), \mathrm{L}_{3}(15.60 \pm 0.68)$ and lowest in $\mathrm{L}_{1}$ $(12.21 \pm 0.78)$ lactation. In the present investigation no specific trend of PMY was noticed for different lactation.

\section{References}

Ambhore, G.S., Avtar Singh, Deokar, D.K., Gupta, A.K., Manvendra, Singh and VedPrakash.(2017). First lactation production and reproduction performance of Phule Triveni cattle in hot arid region of Maharashtra. Indian J.Anim.Sci. 87(1): 105-108.

Arya, V.K. and Tailor, S.P. (2013). Factors affecting production and reproduction traits of Gir and crossbred cattle. Journal Progressive Agriculture. 4(1): 135-138.

Balbir, Khadda, Lavania P. and Pathodiya O.P. (2011). Peak milk yield and days to attain peak yield in Tharparkar cattle. Journal of Progressive Agriculture. 2(1): 145-149. 
Baranwal A., Neerasa G. S., Pruthviraj D.R., BabuLalSaini, SatishKumar and Avneesh Kumar. (2018). Effect of Environmental Factors on Production and Reproduction Traits of Vrindavani Cattle. International Journal of Livestock Research eISSN: 2277-1964, 8 (06):113-122.

Behera R., Mandal A., Rai S., Karunakaran M. and Mondal M. (2020). Temperature Humidity Index and its relationship with production traits of dairy cattle and buffaloes - Review. International Journal of Livestock Research 10(3): 3848.

Bhutkar S.S., B. M. and Bainwad D.V. (2014). Effect of non-genetic factors on production traits in Deoni Cows IOSR Journal of Agriculture and Veterinary Science: 7(12) 2319-2380.

Chakravarthy, A.K., Bidarkar, D.K., Gupta, B.R. Nirsimharao, G. and Sudhakar, K. (2002). Production and reproduction traits of in Ongole cattle. Indian J. Anim. Sci. 72(10): 908-910.

Deokar, D.K., Pachpute, S.T., Kale, S.V. and Naikare, B.D. (2003). Studies on fat corrected milk yield in two and three breed Gir crosses. J. Maharashtra Agric. Univ. 28(1):72-74.

Gaikwad, U.S., Deokar, D.K. and Bhoite, U.K.(2018). Studies on first lactation production traits of Hf x Girhalfbreds. $J$. Anim. Vet. Sci. 5(2):12-15.

Hadge, M.R., Kuralkar, S.V., Ali, S.Z., Kharkar, K.P. and Sawaimul, A.D. (2012). Genetic studies on productive traits of Sahiwal and Jersey x Sahiwal crossbred cows. Indian J. Anim. Res. 46(1): 92-94.

Harvey W.R. (1990).Least-squares analysis of data with unequal subclass numbers.ARS H-4, U.S.D.A, Washington.

Hassan, F. and Khan, M.S. (2013). Performance of crossbred dairy cattle at military dairy farms in Pakistan. J. Anim. Plant Sci. 23(3): 705-714

Jadhav, S.S., Deshmkh, A.R., Deokar, D.K. and
Fulpagare, Y.G., (2010). Effect of non genetic factors on production traits of Girhalfbreds. Asian J.Anim.sci.5(1):2324.

Jadhav, P.D. (2011). Generation wise comparative reproduction and production performance of HF $\mathrm{x}$ Gir and Phule Triveni synthetic cows. M.Sc (Agri.) Thesis submitted to M.P.K.V., Rahuri.

Jadhav, S.S., Deokar, D.K., Fulpagare,Y.G., Bhoite, U.V., Mandakmale, S.D. and Nimbalkar, C.A. (2019). Effects of genetic and non-genetic factors on first lactation production and reproduction traits in HF $x$ Gir cattle. Int.J.Curr.Microbio.App.Sci. 8(1):45-51.

Kamble V.P., Deokar D.K. and Bhoite U.Y.(2016). Studies on first lactation production traits of Phule Triveni. J.Agric.Res.Technol. 41(1): 135-141.

Kale, D.D., Ulmel, B.R., Deokar, D.K. and Pachpute, S.T. (2001). Genetic studies on peak milk yield in Triple crossbred cows. J. Maharashtra Agric.Univ. 26(2):216-218.

Khade P.B. (2001). Studies on herd structure of Holstein Friesian crosses in relation with production performance at R.C.D.P. on cattle Rahuri.M.Sc (Agri.) Thesis submitted to M.P.K.V., Rahuri.

Kramer, C.V. (1957). Extension of multiple range test to group correlated adjusted mean. Biometrics, 13: 13-20.

Kulkarni, P.P. (2001). Persistency of milk yield in Red Sindhi Cattle. M.Sc. (Agri.) Thesis submitted to M.P.K.V., Rahuri.

Mote, M.G., Nimbalkar, C.A., Deokar, D.K. and Gaikwad, U.S. (2019). Effect of genetic and non-genetic factors on first lactation production traits in crossbreds of Gir with Holstein friesion and Jersey cattle breeds. Agric.Ress.:1-5.

Mruttu, H. A. (2013). Studies on performance of Deoni cattle at MAU dairy farm, Parbhani,Ph.D thesis submitted to Marathwada Agriculture University, Parbhani (MS).

Nanavati, S. and Singh, A. (2004).Non-genetic 
factors affecting production traits in Gir cattle. Indian J. Dairy Sci. 57 (5): 342346.

Pandey M. and Raja K.N., Saleem Yousuf and Gupta A.K. (2018). Effect of nongenetic factors on first lactation 305 days and lifetime milk yield in Sahiwal cattle. Indian J Dairy Sci 72(1): 89-92.

Patond, M.N. (2009). Persistency of milk yield in Jersey cattle. M.Sc. (Agri.) Thesis submitted to M.P.K.V., Rahuri.

Patond, M.N. (2013). Modelling of lactation curve in Gir triple cross cows. Ph. D. Thesis submitted to M.P.K.V., Rahuri.

Pol, K.E., Dhage, S.A., Pachpute, S.T. and Khutal, B.B. (2013). Generation wise production efficiency of Phule Triveni synthetic cow. J. Agric. Res. Technol. 38(1): 117-129.

Radhika G., AjithkumarS.,Rani A.,Sathian C.T., Anilkumar K., Usha A. P. and Dinesh C.N. (2012). Milk yield and composition of crossbred cows in the hilly Wayanad district of Kerala, India. Indian Journal of Animal Sciences 82 (10): 1251-1254.

Raut, D.R., Deokar, D.K., Bhoite, U.Y., Gaikwad, U.S. and Mandakmale, S.D., (2017). Prediction of 305 days milk yield from part lactation records in $\mathrm{HF}$ Girhalfbred cows. Contemporary Research in India. 7(2):193-196.

Roy, P.K., Basu, S.B. and Pachlang, S.V. (1993). Association between milk production and reproduction traits in crossbred cows. Indian J. Dairy Sci. 45(6) 274-277.

Shelke, M.G. (2012). Generation wise persistency of milk production in Phule Triveni Synthetic cows M. Sc. (Agri.) Thesis submitted to M.P.K.V., Rahuri.

Shubha Lakshmi, B., Ramesh Gupta, B., Sudhakar, K., G Prakash. and Lt. Col. Susheel Sharma. (2009). Genetic analysis of production performance of Holstein Friesian $x$ Sahiwal cows. Tamilnadu J. Vet. Anim. Sci. 5(4): 143148.

Thakur, Y.P. and Singh, B.P. (2001). Factors affecting first lactation milk yield traits in Jersey crossbred cows. Indian $J$. Anim. Res. 39(2): 115-118.Thombare, B.M., Bainwad, D.V., ZewduWondifraw (2013). Effect of non-genetic factors on milk production of Holstein Friesian $\mathrm{x}$ Deoni crossbred cows. Af. J. Dairy Farming milk prod.1(4): 79-84.

Thombare, B.M., Bainwad, D.V., Zewdu Wondifraw (2013). Effect of non-genetic factors on milk production of Holstein Friesian x Deoni crossbred cows. Af. $J$. Dairy Farming milk prod. 1(4): 79-84.

Usman, T., Suhail, S. M., Ahmed, S., Qureshi, M. S. and Wang, Y. (2012). Performance traits study of Holstein Friesian cattle under subtropical conditions. J. Anim. Plant Sci. 22 (2):9295.

Zol, S.R. (2007). Studies on generation wise breeding efficiency of Phule Triveni crossed cows at R.C.D.P organized farm. M.Sc.(Agri.) Thesis submitted to M.P.K.V., Rahuri.

\section{How to cite this article:}

Ghoshita Suryakant Hingonekar, Dilip Kundalik Deokar, Swapnali Uttamrao Rokade and Harshavardhan Shahaji Sonawane. 2021. Effect of Non-genetic Factors on Production Traits of for HF $\times$ GIR Halfbreds. Int.J.Curr.Microbiol.App.Sci. 10(01): 178-185.

doi: https://doi.org/10.20546/ijcmas.2021.1001.021 